\title{
PENGEMBANGAN PERANGKAT PEMBELAJARAN BERBASIS MASALAH UNTUK MENINGKATKAN KEMAMPUAN KOMUNIKASI MATEMATIS DAN SELF-EFFICACY SISWA SMP
}

\author{
Dewi Perwitasari ${ }^{1}$
}

\begin{abstract}
ABSTRAK
Penelitian ini bertujuan untuk mendeskripsikan: (1) validitas perangkat pembelajaran berbasis masalah yang dikembangkan, (2) kepraktisan perangkat pembelajaran berbasis masalah yang dikembangkan, (3) efektivitas perangkat pembelajaran dengan menggunakan perangkat pembelajaran berbasis masalah yang dikembangkan, (4) peningkatan kemampuan komunikasi matematis siswa dengan menggunakan perangkat pembelajaran berbasis masalah, dan (5) peningkatan self-efficacy siswa melalui angket (6) proses jawaban siswa dalam menyelesaikan tes komunikasi matematis. Penelitian ini merupakan penelitian pengembangan dengan model Dick and Carey. Ujicoba I dilakukan pada siswa kelas VII-1 dan ujicoba II di kelas VII-2 SMP Negeri 23 Medan. Instrumen penelitian ini adalah lembar observasi aktivitas siswa, kemampuan guru mengelola pembelajaran, angket respon siswa serta tes kemampuan komunikasi matematis. Perangkat pembelajaran yang dikembangkan (Buku Guru, Buku siswa dan LKS). Dari hasil penelitian diperoleh bahwa: 1) perangkat pembelajaran yang dikembangkan memenuhi kriteria valid, baik dalam validitas isi maupun konstruk. 2) perangkat pembelajaran yang dikembangkan memenuhi kriteria praktis, ditinjau dari : a) penilaian validator dan , b) keterlaksanaan perangkat pembelajaran. 3) perangkat yang dikembangkan telah memenuhi efektivitas proses pembelajaran, dimana: (a) persentase ketuntasan belajar siswa adalah 92,5\% secara klasikal dari 40 orang siswa yang mengikuti tes dengan nilai minimal 2,67 (B'); (b) kadar aktivitas siswa telah memenuhi batas toleransi waktu ideal; dan (c) respon siswa terhadap proses pembelajaran sudah positif pada ujicoba I maupun ujicoba II; 4) terjadi peningkatan rata-rata kemampuan komunikasi matematis siswa pada postes ujicoba I ke ujicoba II ; (5) terdapat peningkatan self-efficacy siswa yang diujikan melalui angket; dan (6) proses jawaban siswa pada uji coba II lebih baik dari Uji coba I.
\end{abstract}

Kata Kunci: Pengembangan Perangkat Pembelajaran, Pembelajaran Berbasis Masalah, Model Pengembangan Dick and Carey, Kemampuan Komunikasi Matematis, Self-Efficacy.

\begin{abstract}
This study aims to describe: (1) the validity of the developed problem-based learning materials, (2) the practicality of the developed problem-based learning materials, (3) the effectiveness of learning materials using the developed problem-based learning materials, (4) the increasing of mathematical communication skills students using problembased learning materials, and (5) the increasing of student self-efficacy through questionnaires (6) the students' solution processes in completing mathematical communication tests. This study is a development research using the Dick and Carey model. The trial I and trial II of each was conducted on class VII-1 and VII-2 SMP Negeri 23 Medan. The instrument was the student activity observation sheet, the teacher's ability to manage learning process, the questionnaires of students' response and the tests of mathematical communication skills. The learning materials include teacher's books, student's books and student's worksheets. From the study results, it is found that: 1) the learning materials were in the valid criterias, both in content and construct validity; 2) the learning materials were in the practical criterias, in terms of: a) validator assessment and, b) the implementation of learning materials; 3) the learning materials were in the effective criterias of the learning process, where: (a) the percentage of student learning mastery is $92.5 \%$ classically from 40 students who took the test with a minimum score of 2.67 (B-); (b) the level of student activity was in the ideal time tolerance limit; and (c) the student's response to the learning process was positive in trial I and II; 4) there was an increasing in the average of students' mathematical communication skills from posttest in the trial I to trial II; (5) there is an increasing of student self-efficacy who was tested through a questionnaire; and (6) the student's solution process in trial II was better than trial I.
\end{abstract}

Keywords: Development of Learning Materials, Problem Based Learning, Dick \& Carey Design Model, Mathematical Communication Skills, Self-Efficacy.

\section{PENDAHULUAN}

Masalah pendidikan matematika erat kaitannya dengan masalah pembelajaran matematika itu sendiri. Pembelajaran merupakan salah satu unsur dalam pelaksanaan pendidikan sehingga kualitas pendidikan berkaitan erat dengan kualitas pembelajaran. Dalam proses pembelajaran, kurangnya penguasaan konsep dengan benar mengakibatkan siswa tidak dapat

${ }^{1}$ Pengawas Dinas Pendidikan Kota Medan, Medan, 20236, Indonesia E-mail: dewiperwitasari70@gmail.com mengembangkan konsep yang dimiliki untuk menyelesaikan masalah, akhirnya siswa cenderung menghapal rumus-rumus serta langkah-langkah penyelesaian yang diberikan secara konvensional. Untuk itu salah satu usaha yang dilakukan adalah meningkatkan kemampuan para guru. Salah satu kemampuan yang diharapkan adalah bagaimana membuat proses pembelajaran matematika yang efektif sehingga tujuan pengajaran optimal dapat dicapai semaksimal mungkin. 
Vol. 14, No. 1, Juni 2021

Seorang guru matematika yang tidak menguasai materi pelajaran yang akan diajarkan tidak mungkin dapat mengajar dengan baik, demikian juga bila guru tidak dapat memilih metode yang tepat pada materi yang diajarkan maka pengajaran pun tidak memberikan hasil yang optimal. Sebagaimana yang diutarakan Soedjadi (2000:71) "Bagaimana seorang guru berusaha menguasai matematika yang akan diajarkannya serta bagaimana mengajarkannya kepada siswa yang tengah berkembang, merupakan seni atau kiat tersendiri. Tidaklah benar kalau ada anggapan bahwa seseorang yang telah menguasai matematika dengan baik, akan dengan sendirinya mampu mengajarkannya dengan baik pula".

Untuk menciptakan pembelajaran yang menarik, guru diberi tuntutan dalam mempersiapkan perangkat pembelajaran yang meliputi Rencana Pelaksanaan Pembelajaran (RPP), Lembar Kerja Siswa (LKS), buku ajar, dan lainnya.

Perangkat pembelajaran merupakan komponen terpenting yang harus dipersiapkan oleh guru sebelum melaksanakan proses pembelajaran. Perangkat pembelajaran hendaknya tidak hanya memberikan materi secara instan, tetapi mampu menggiring siswa kepada kemampuan untuk mengerti konsep yang dipelajari.

Pengembangan perangkat pembelajaran diharapkan sesuai dengan standar proses yang telah ditetapkan oleh National Council of Teachers of Mathematics (NCTM). Standar proses dalam pembelajaran matematika yang dikeluarkan NCTM merupakan salah satu pencapaian tujuan pembelajaran matematika. Standar-standar kemampuan matematis yang ditetapkan oleh NCTM, yaitu kemampuan matematis, meliputi pemecahan masalah, penalaran, komunikasi, koneksi, dan representasi, yang harus dimiliki oleh setiap siswa.

Ogden (Mehdinezhad, 2012:21) menemukan bahwa dari 383 responden, 64,8 persensetuju dengan pernyataan: "Penekanan yang harus lebih ditekankan adalah pada keterampilan komunikasi", mengusulkan bahwa mayoritas siswa di nilai dengan cara keterampilan komunikasinya. Pada kenyataannya masih timbul permasalahan yang dihadapi siswa, khususnya kurangnya kemampuan komunikasi matematis siswa. Oleh karena itu, kemampuan berkomunikasi menjadi tuntutan khusus. Amalia (Oktaviarini, 2015:80) mengemukakan bahwa manfaat dari sebuah komunikasi dalam pembelajaran matematika dapat mendorong siswa belajar konsep baru dalam matematika, karena dalam belajar matematika siswa dapat mengunakan alat atau benda, menggambar, memberikan penjelasan atau pertimbangan, menggunakan diagram, menulis, dan menggunakan symbol matematika. Cockroft (Shadiq, 2004:14). menyatakan kita percaya bahwa semua anggapan kegunaan matematika muncul dari fakta bahwa pembuktian matematika berarti komunikasi yang sangkat kuat, ringkas dan jelas. Namun, kenyataan di sekolah, kemampuan komunikasi matematis siwa masih rendah. Hal ini terlihat dari salah satu jawaban siswa kelas VIII SMP yang menunjukkan kurangnya kemampuan komunikasi matematis dalam menggunakan tabel dan grafik yang menggambarkan suatu data pada Gambar 1. Pada gambar tersebut, siswa hanya menggambarkan grafik sesuai dengan urutan data yang diberikan, tanpa melihat urutan penggambaran nilai pada tabel dan grafik yang benar.

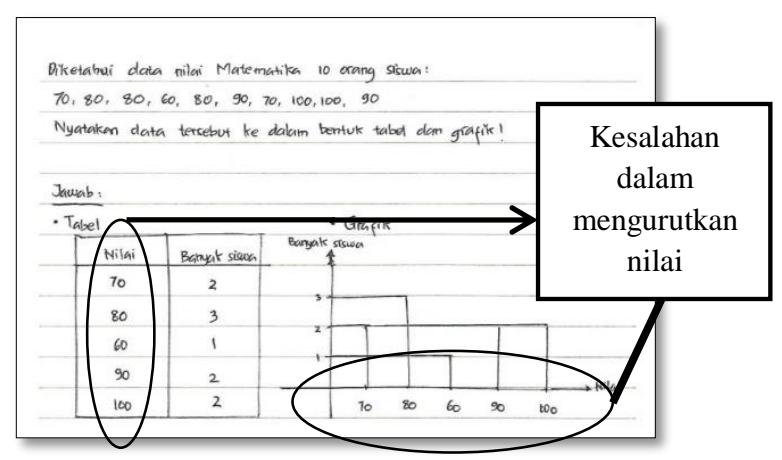

Gambar 1. Proses jawaban siswa dalam mengkomunikasikan data ke dalam grafik masih salah

Shanon (Wiryanto, 2004:73), mendefinisikan komunikasi sebagai bentuk interaksi manusia yang saling mempengaruhi satu sama lain, sengaja atau tidak sengaja dan tidak terbatas pada bentuk pada bentuk komunikasi verbal, tetapi juga dalam hal ekspresi muka, lukisan, seni, dan teknologi.Dalam pembelajaran matematika, terdapat kemampuan komunikasi matematis yang merupakan salah satu kemampuan yang menjadi tolak ukur ketercapaian siswa dalam pembelajaran. NCTM (2000:4) menyatakan bahwa komunikasi matematis adalah cara berbagi ide dan memperjelas pemahaman. Ketika siswa tertantang untuk mengkomunikasikan hasil pemikiran mereka untuk orang lain secara lisan atau tertulis, mereka belajar untuk menjadi menjelaskan, meyakinkan, dan menggunakan bahasa matematika dengan tepat.

Selain kemampuan komunikasi matematis, kemampuan self-efficacy siswa juga memberikan dampak dalam proses pembelajaran. Bandura (dalam Habibah,2012:24) mendefinisikan Self-efficacy sebagai keyakinan orang tentang kemampuan mereka untuk menghasilkan tingkat kinerja yang ditunjuk bahwa latihan pengaruh atas peristiwa yang mempengaruhi kehidupan mereka. Bandura (1997: 116) menjelaskan bahwa self-efficacy mempunyai efek pada perilaku manusia melalui empat proses yaitu proses kognitif, proses motivasi, proses afeksi dan proses seleksi.

Menurut Joyce (2011:3) sikap konstruktivis adalah bahwa pengetahuan tidak sekedar ditransmisikan oleh guru atau orang tua, tetapi harus dibangun sendiri oleh siswa agar mereka dapat merespon informasi dalam lingkungan pendidikan. Pembelajaran konstruktivisme menempatkan siswa pada peranan utama selama proses pembelajaran (student centered). Oleh karena itu guru dituntut untuk selalu berinovasi dalam melaksanakan pembelajaran. Sehubungan dengan hal itu, guru sebagai tenaga pendidik hendaknya mampu memilih model pembelajaran serta media yang tepat dalam proses pembelajaran untuk memperoleh hasil belajar 
yang diharapkan. Guru sebaiknya mengembangkan kegiatan dalam pembelajaran adalah dengan menginovasikan suatu model pembelajaran yang menarik dan menciptakan situasi belajar yang melibatkan siswa secara aktif.

Salah satu alternatif model pembelajaran yang dapat meningkatkan kemampuan komunikasi dan selfefficacy siswa adalah pembelajaran berbasis masalah. Wulandari (2013:182) mengemukakan keunggulan PBM diantaranya dapat meningkatkan aktivitas pembelajaran, membantu proses transfer siswa untuk memahami masalah-masalah dalam kehidupan seharihari, dan membantu siswa mengembagkan pengetahuannya dan membantu siswa untuk bertanggungjawab atas pembelajarannya sendiri .

Dari uraian diatas dapat diketahui bahwa kemampuan komunikasi matematis dan self-efficacy siswa sangat penting dalam proses pembelajaran, namun kurang menjadi fokus dalam pembelajaran itu sendiri. Untuk itu peran guru sebagai fasilitator sangat penting untuk mencapai tujuan pembelajaran yang diharapkan. Disamping pemilihan model pembelajaran yang diterapkan, diperlukan adanya pengembangan perangkat pembelajaran yang sesuai dengan model yang diterapkan. Untuk bisa menerapkan model pembelajaran berbasis masalah dengan efektif, maka diperlukan adanya perangkat pembelajaran yang mendukung dengan efektif pula.

Paparan model pembelajaran serta kelemahankelemahan perangkat pembelajaran menunjukkan bahwa kualitas perangkat pembelajaran yang tersedia belum tergolong baik. Untuk itu, perlu dilakukan pengembangan perangkat pembelajaran yang berkualitas, sesuai dengan kondisi dan karakteristik siswa SMP. Kualitas perangkat yang dikembangkan dirancang agar memenuhi kriteria valid, praktis dan efektif serta sesuai dengan kurikulum yang berlaku. Perangkat pembelajaran yang dikembangkan disusun mengacu pada model pembelajaran berbasis masalah, diantaranya: Buku Guru (BG), Buku Siswa (BS) dan Lembar Kerja Siswa (LKS).

Berdasarkan latar belakang diatas, peneliti tertarik untuk melakukan penelitian dengan judul "Pengembangan Perangkat Pembelajaran Berbasis Masalah untuk Meningkatkan Kemampuan Komunikasi dan Self-Efficacy Siswa SMP”.

\section{METODE PENELITIAN}

Penelitian ini termasuk penelitian pengembangan (development research) dengan menggunakan model pengembangan perangkat pembelajaran Dick and Carey, yang terdiri dari 10 tahap pengembangan. Penelitian ini dilaksanakan di SMP Negeri 23 Medan yang merupakan salah satu sekolah menengah pertama negeri di Kota Medan, Sumatera Utara. Penelitian ini akan dilaksanakan pada semester genap tahun ajaran 2016/2017 pada materi statistika.

Instrumen yang digunakan dalam penelitian ini adalah tes kemampuan komunikasi matematis siswa dan angket self-efficacy. Teknik pengumpulan data yang digunakan adalah teknik tes dan angket. Data hasil validasi dianalisis dengan kriteria penilaian dengan pendeskripsian rerata skor dan uji statistik. Kepraktisan perangkat dilihat dari ahli dan hasil keterlaksanaan perangkat pembelajaran. Kefektifan perangkat dilihat dari ketuntasan klasikal kemampuan komunikasi matematis siswa, aktivitas siswa, dan respon positif siswa.

\section{HASIL PENELITIAN}

\section{Analisis Identifikasi Tujuan Instruksional}

Tahap awal model ini adalah mengidentifikasi tujuan instruksional, tujuannya adalah untuk menentukan kompetensi yang diharapkan dapat dikuasai dan dilakukan oleh siswa setelah selesai pembelajaran. Tujuan ini ditentukan dari analisis pelaksanaan pembelajaran, dari tes yang diberikan dan dari berbagai kesulitan belajar siswa.

Berdasarkan hasil observasi di SMP Negeri 23 Medan, menunjukkan bahwa kemampuan komunikasi matematis siswa rendah. Hal ini terlihat berdasarkan hasil jawaban siswa terhadap tes diagnostik yang diberikan. Berdasarkan hasil tes yang diujikan kepada 20 orang siswa. Tes yang diberikan adalah tes kemampuan komunikasi matematis. Hasil tes tersebut menunjukkan sangat sedikit siswa yang mampu mencapai nilai ketuntasan belajar yaitu B- $(2,67)$.

Berdasarkan hasil observasi terhadap perangkat pembelajaran di SMP Negeri 23 Medan ditemukan beberapa kelemahan pada perangkat pembelajaran yang digunakan oleh guru dimana secara tidak langsung menjadi salah satu faktor rendahnya kemampuan komunikasi matematis dan self-efficacy siswa. Perangkat pembelajaran yang digunakan masih berpusat pada guru sehingga kecederungan siswa untuk aktif dalam pembelajaran sangat kecil. Berdasarkan RPP yang digunakan oleh guru, RPP belum dikembangkan sesuai kondisi karakteristik siswa dan kebutuhan siswa terhadap materi yang dipelajari.

Buku Siswa (BS) yang digunakan di SMP Negeri 23 Medan belum menerapkan teori konstruktivisme. Buku siswa cenderung memberikan konsep materi terlebih dahulu kemudian memberikan contoh masalah. Hal ini bertentangan dengan teori konstruktivisme. Siswa terlebih dahulu diberikan masalah dan menarik kesimpulan berdasarkan pengetahuannya sendiri sehingga terbentuk konsep materi yang dipelajari dan kemampuan komunikasi siswa dapat meningkat.

Berdasarkan pembahasan di atas, telah dipaparkan masalah utama yang terdapat dalam pembelajaran di SMP Negeri 23 Medan. Masalah tersebut berupa rendahnya kualitas perangkat pembelajaran yang digunakan di SMP Negeri 23 Medan yang berdampak pada rendahnya kemampuan komunikasi matematis dan self-efficacy siswa. Untuk mengatasi masalah tersebut, dikembangkan perangkat pembelajaran yang memenuhi kriteria valid, praktis, dan efektif yang penerapannya akan berdampak pada peningkatan kemampuan komunikasi matematis dan self-efficacy siswa SMP Negeri 23 Medan. 
Vol. 14, No. 1, Juni 2021

\section{Menganalisis Tingkah Laku Awal/ Karakteristik Siswa}

Pada tahap ini, analisis yang dilakukan terhadap siswa SMP Negeri 23 Medan, yang mana cara umum, kemampuan akademik siswa SMP Negeri 23 Medan memasuki tahap operasional formal. Hal ini terlihat dari usia siswa SMP Negeri 23 Medan yang berada pada rentang usia 12-14 tahun. Menurut Piaget (Trianto, 2009:30) perkembangan kognitif siswa pada usia tersebut adalah tahap operasional formal.

Hasil analisis kemampuan akademik siswa SMP Negeri 23 Medan tergolong rendah. Hal ini berdasarkan hasil wawancara dengan salah satu guru matematika SMP Negeri 23 Medan, yang menyatakan bahwa hasil ujian semester ganjil siswa kelas VII hampir 35\% tidak mencapai 2,67 (B-). Proses pembelajaran yang dilakukan di SMP Negeri 23 Medan diawali dengan menjelaskan konsep dari materi yang akan dipelajari, memberikan contoh soal dan diakhiri dengan pemberikan latihan berupa soal yang mirip dengan contoh soal. Selain kemampuan komunikasi matematis, self-efficacy siswa SMP Negeri 23 Medan juga tergolong rendah. Hal ini dapat disimpulkan berdasarkan hasil wawancara dengan guru matematika.

Penerapan perangkat pembelajaran yang dikembangkan ini diharapkan berdampak pada peningkatkan kualitas pembelajaran matematika yang difokuskan pada peningkatan kemampuan komunikasi matematis dan self-efficacy siswa.

\section{Merumuskan Tujuan Kegiatan Pembelajaran}

Berdasarkan analisis instruksional dan pernyataan tentang tingkah laku awal siswa, selanjutnya dirumuskan pernyataan khusus tentang apa yang harus dilakukan siswa setelah menyelesaikan pembelajaran. Indikator/tujuan pembelajaran disesuaikan dengan standar kompetensi dan kompetensi dasar kurikulum K13, yaitu:

\section{Pertemuan pertama:}

Memahami penyajian data

1) Siswa dapat menyajikan data dalam bentuk table

\section{Pertemuan kedua:}

Memahami penyajian data

1) Siswa dapat menyajikan data dalam bentuk diagram batang

2) Siswa dapat menyajikan data dalam bentuk diagram garis

3) Siswa dapat menyajikan data dalam bentuk diagram lingkaran

\section{Pertemuan ketiga:}

Memahami konsep ukuran penyebaran data

1) Siswa dapat menentukan nilai rata-rata

2) Siswa dapat menentukan nilai median

3) Siswa dapat menentukan nilai modus

\section{Hasil Validasi Tim Ahli}

Uji validitas dilakukan untuk melihat kekurangan dari dfrat I baik dari segi isi (content) yang berisikan kompetensi dasar, materi, contoh soal, soal latihan dan evaluasi pada setiap akhir sub bab serta kesesuaiannya dengan model pembelajaran berbasis masalah. Tim ahli (validator) yang terlibat dalam pengembangan perangkat pembelajaran ini terdiri dari lima orang ahli yang terdiri dari 3 Dosen dan 2 Guru SMP. Tabel 1 adalah rekapitulasii hasil validasi perangkat pembelajaran oleh ahli.

Tabel 1. Rekapitulasi Hasil Validasi Perangkat oleh Ahli

\begin{tabular}{cccc}
\hline No. & Objek yang dinilai & $\begin{array}{c}\text { Nilai rata- } \\
\text { rata total } \\
\text { validitas }\end{array}$ & $\begin{array}{c}\text { Tingkat } \\
\text { Validasi }\end{array}$ \\
\hline 1. & Lembar Kerja Siswa & 4,49 & Valid \\
\hline 2. & Buku Guru (BG) & 4,45 & Valid \\
\hline 3. & Buku Siswa (BS) & 4,51 & Valid \\
\hline
\end{tabular}

Berdasarkan kriteria kevalidan maka dapat dikatakan bahwa bahan ajar yang dikembangkan dapat digunakan atau dalam kategori "Valid".

\section{Uji Coba Terbatas \\ Validitas Instrument Penelitian}

Validitas soal dianalisa dengan menggunakan rumus korelasi product moment pearson yaitu dengan mengkorelasikan skor item soal dengan skor total. Adapun hasil Uji coba instrumen tes kemampuan komunikasi matematis disajikan pada Tabel 2.

Tabel 2. Validitas Butir Post-test Kemampuan Komunikasi Matematis Siswa

\begin{tabular}{ccccc}
\hline $\begin{array}{c}\text { Butir } \\
\text { soal }\end{array}$ & $\boldsymbol{r}_{\boldsymbol{x y}}$ & $\boldsymbol{t}_{\text {hitung }}$ & $\boldsymbol{t}_{\text {tabel }}$ & Interpretasi \\
\hline 1. & 0,895 & 10,635 & 2,05 & Valid \\
\hline 2. & 0,665 & 4,719 & 2,05 & Valid \\
\hline 3. & 0,718 & 5,473 & 2,05 & Valid \\
\hline 4. & 0,632 & 4,316 & 2,05 & Valid \\
\hline 5. & 0,891 & 10,391 & 2,05 & Valid \\
\hline
\end{tabular}

Berdasarkan data pada tabel di atas, interpretasi dari masing-masing butir post-test berada pada kategori Valid. Untuk hasil perhitungan dengan menggunakan rumus alpha-Cronbach diperoleh reabiltas untuk post-test adalah 0,822 .

\section{Uji Coba I dan Uji Coba II}

\section{Deskripsi Kepraktisan Perangkat Pembelajaran}

Penilaian Validator terhadap Perangkat Pembelajaran

Analisis berdasarkan respon para ahli dan praktisi menyatakan perangkat pembelajaran berbasis masalah yang dapat dikembangkan secara umum baik dan dapat digunakan dengan sedikit revisi. Penilaian ini diberikan pada para ahli dan praktisi sekaligus dengan pemberian lembar validasi perangkat. Adapun hasil pemberian lembar validasi perangkat pada validator terkait respon perangkat yang dikembangkan dapat dilihat pada Tabel 3 .

Tabel 3. Penilaian Validator terhadap Perangkat yang Dikembangkan

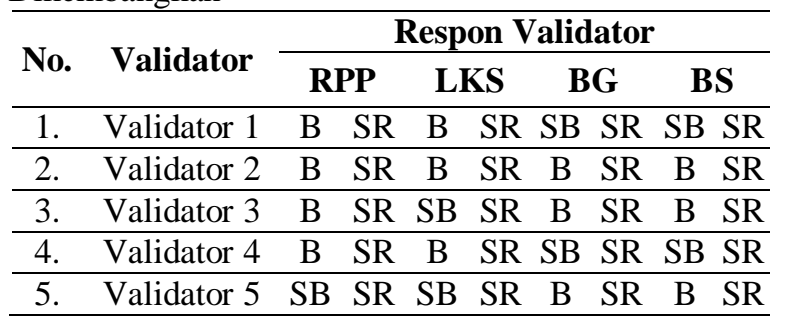


Keterangan:

B :Perangkat yang dikembangkan berkategori baik;

SB : Perangkat yang dikembangkan berkategori sangat baik;

SR : Perangkat yang dikembangkan dapat digunakan dengan sedikit revisi;

\section{Keterlaksanaan Perangkat Pembelajaran}

Keterlaksanaan seluruh perangkat pembelajaran yang digunakan dalam penelitian diamati oleh seorang observer yang merupakan guru bidang studi matematika pada setiap pertemuan yang dilakukan. Adapun persentase keterlaksanaan perangkat dari Uji coba I dan uji coba II, terlihat pada Gambar 2.

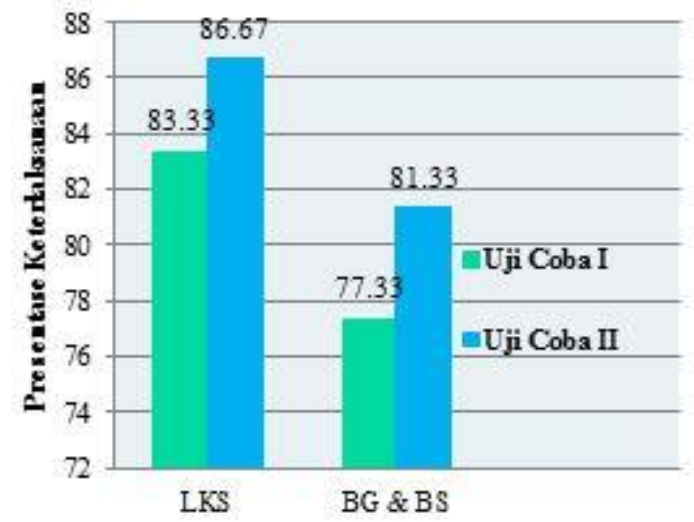

Gambar 2. Hasil Presentase Keterlaksanaan

Perangkat

Pada uji coba I, Rata-rata keterlaksanaan perangkat pembelajaran menjadi 80,33. Pada uji coba II, Rata-rata keterlaksanaan perangkat pembelajaran menjadi 84. Sehingga dapat disimpulakn bahwa Perangkat Pembelajaran yang dikembangkan praktis.

\section{Efektivitas Perangkat Pembelajaran}

Adapun data hasil ketuntasan klasikal uji coba I dan uji coba II untuk kemampuan komunikasi matematis dapat dilihat pada Tabel 4. di bawah.

Tabel 4. Tingkat Ketuntasan Klasikal Kemampuan Komunikasi Matematis Siswa Pada Uji Coba I dan Uji Coba II

\begin{tabular}{lcccc}
\hline \multicolumn{1}{c}{ Kategori } & \multicolumn{2}{c}{$\begin{array}{c}\text { Hasil Post test } \\
\text { Uji Coba I }\end{array}$} & \multicolumn{2}{c}{$\begin{array}{c}\text { Hasil Post test } \\
\text { Uji Coba II }\end{array}$} \\
\hline Tuntas & 30 & $75 \%$ & 37 & $92,5 \%$ \\
\hline Tidak Tuntas & 10 & $25 \%$ & 3 & $7,5 \%$ \\
\hline Jumlah & 40 & $100 \%$ & 40 & $100 \%$ \\
\hline
\end{tabular}

Berdasarkan Tabel 4 di atas, diketahui bahwa ketuntasan klasikal uji coba I adalah 75\%, dan uji coba II adalah 92,5\%. Sehingga pada uji coba I belum mencapai kategori efektif yaitu $85 \%$, sedangkan uji coba II ketuntasalan klasikal sudah memenuhi kategori yaitu $85 \%$.

Analisis angket respon siswa ini dilakukan untuk melihat sejauh mana ketertarikan siswa, perasaan senang dan keterkinian serta kemudahan dalam memahami komponen-komponen seperti materi/isi bahan ajar, format, gambar-gambarnya, kegiatan dalam lembar kerja siswa dan suasana belajar. Sedangkan untuk hasil respon siswa terhadap perangkat pada Uji Coba I dan II pada tabel 5.

Tabel 5. Hasil Respon Siswa Terhadap Perangkat pada Uji Coba I dan Uji Coba II

\begin{tabular}{|c|c|c|c|c|c|}
\hline \multirow{2}{*}{ No. } & \multirow{2}{*}{ Aspek } & \multicolumn{2}{|c|}{$\begin{array}{c}\begin{array}{c}\text { Rata-rata Uji } \\
\text { Coba I }\end{array} \\
\end{array}$} & \multicolumn{2}{|c|}{$\begin{array}{c}\text { \% Rata-rata Uji } \\
\text { Coba II }\end{array}$} \\
\hline & & Senang & \begin{tabular}{|c|} 
Tidak \\
Senang
\end{tabular} & Senang & \begin{tabular}{|c|} 
Tidak \\
Senang
\end{tabular} \\
\hline \multirow[t]{2}{*}{1.} & $\begin{array}{l}\text { Apakah kamu } \\
\text { merasa senang } \\
\text { atau tidak } \\
\text { terhadap } \\
\text { komponen } \\
\text { pembelajaran } \\
\text { berikut ini? }\end{array}$ & 78,5 & 21,5 & 89,2 & 10,2 \\
\hline & & Baru & $\begin{array}{l}\text { Tidak } \\
\text { Baru }\end{array}$ & Baru & $\begin{array}{l}\text { Tidak } \\
\text { Baru }\end{array}$ \\
\hline \multirow[t]{2}{*}{2.} & $\begin{array}{l}\text { Apakah } \\
\text { komponen } \\
\text { pembelajaran } \\
\text { berikut ini } \\
\text { bagimu baru } \\
\text { atau tidak? }\end{array}$ & 84,5 & 15,5 & 89 & 11 \\
\hline & & Berminat & $\begin{array}{c}\text { Tidak } \\
\text { Berminat } \\
\end{array}$ & Berminat & $\begin{array}{c}\text { Tidak } \\
\text { Berminat } \\
\end{array}$ \\
\hline \multirow[t]{2}{*}{3.} & $\begin{array}{l}\text { Apakah kamu } \\
\text { berminat atau } \\
\text { tidak mengikuti } \\
\text { kegiatan } \\
\text { pembelajaran } \\
\text { selanjutnya } \\
\text { seperti yang } \\
\text { baru saja kamu } \\
\text { ikuti? }\end{array}$ & 80 & 20 & 90 & 10 \\
\hline & & Ya & Tidak & Ya & Tidak \\
\hline \multirow[t]{2}{*}{4.} & $\begin{array}{l}\text { Apakah kamu } \\
\text { dapat } \\
\text { memahami } \\
\text { dengan jelas } \\
\text { atau tidak } \\
\text { bahasa yang } \\
\text { digunakan? } \\
\end{array}$ & 82,5 & 17,5 & 88,75 & 11,25 \\
\hline & & $\mathbf{Y a}$ & Tidak & Ya & Tidak \\
\hline 5. & $\begin{array}{l}\text { Apakah kamu } \\
\text { tertarik atau } \\
\text { tidak dengan } \\
\text { penampilan } \\
\text { (tulisan, } \\
\text { ilustrasi/gambar } \\
\text { dan letak } \\
\text { gambar)? }\end{array}$ & 90 & 10 & 92,5 & 7,5 \\
\hline
\end{tabular}

Dari Tabel 5 dapat dianalisis bahwa respon siswa terhadap semua aspek terutama terhadap perangkat pembelajaran yaitu pendapat siswa terhadap komponen pembelajaran yang terdiri dari buku siswa, lembar kerja siswa, dan tes kemampuan komunikasi matematis dapat disimpulkan bahwa respon siswa terhadap komponen dan kegiatan pembelajaran dengan model pembelajaran berbasis masalah adalah positif.

Analisis pencapaian waktu ideal aktivitas siswa ini dilakukan untuk menjaring data lapangan tentang persentase pencapaian waktu ideal setiap aktivitas yang dilakukan siswa pada uji coba I dan II. Aktivitas siswa yang diobservasi mancakup: aktivitas kategori 1 yaitu mendengarkan/memperhatikan penjelasan guru; aktivitas kategori 2 yaitu membaca Buku Siswa dan LKS; aktivitas kategori 3 yaitu mencatat penjelasan guru, mencatat dari buku atau dari teman, 
Vol. 14, No. 1, Juni 2021

menyelesaikan masalah pada LKS, merangkum pekerjaan kelompok; aktivitas kategori 4 yaitu berdiskusi/bertanya antara siswa dan temannya, dan antara siswa dan guru, menarik kesimpulan suatu prosedur atau konsep; serta aktivitas kategori 5 yaitu melakukan sesuatu yang tidak relevan dengan pembelajaran. Dalam menentukan persentase waktu aktivitas siswa, peneliti dibantu oleh pengamat yang mengamati aktivitas siswa sesuai dengan kriteria aktivitas siswa yang telah dijabarkan sebelumnya. Data persentase pencapaian waktu ideal aktivitas siswa untuk lima pertemuan yang masing-masing dilakukan pada uji coba I dan II dapat dilihat pada tabel 6 .

Tabel 6. Hasil pencapaian waktu ideal aktivitas siswa dalam pembelajaran uji coba I dan uji coba II.

\begin{tabular}{|c|c|c|c|c|c|}
\hline $\begin{array}{l}\text { Kategori } \\
\text { Aktivitas }\end{array}$ & 1 & 2 & 3 & 4 & 5 \\
\hline $\begin{array}{l}\text { Rata-rata Uji } \\
\text { coba I }\end{array}$ & 29,17 & 18,75 & 18,05 & 31,59 & 2,43 \\
\hline $\begin{array}{l}\text { Rata-rata uji } \\
\text { coba II }\end{array}$ & 26,82 & 15,37 & 28,91 & 27,86 & 1,04 \\
\hline \multirow{2}{*}{ Kriteria } & $\begin{array}{l}20 \% \\
\leq \text { PWI }\end{array}$ & $\begin{array}{l}10 \% \\
\leq \text { PWI }\end{array}$ & $\begin{aligned} & 25 \% \\
& \leq \text { PWI }\end{aligned}$ & $\begin{aligned} & 25 \% \\
\leq & \mathrm{PWI}\end{aligned}$ & $\begin{aligned} & 0 \% \\
& \leq \mathrm{PWI}\end{aligned}$ \\
\hline & $\begin{array}{c}\leq \\
30 \%\end{array}$ & $\begin{array}{c}\leq \\
20 \%\end{array}$ & $\begin{array}{c}\leq \\
35 \%\end{array}$ & $\begin{array}{c}\leq \\
35 \% \\
\end{array}$ & $\begin{array}{c}\leq \\
5 \%\end{array}$ \\
\hline
\end{tabular}

Dari Tabel 6 dapat disimpulkan bahwa persentase pencapaian waktu ideal aktivitas siswa untuk lima pertemuan yang masing-masing dilakukan pada uji coba I dan II telah memenuhi kriteria yang ditetapkan. Dengan demikian dapat disimpulkan bahwa perangkat pembelajaran berbasis masalah yang dikembangkan efektif ditinjau dari aktivitas siswa.

Dari data keefektifan di atas dapat kita rekaptulasi hasil keefektifan perangkat pembelajaran dapat dilihat pada Tabel 7 berikut.

Tabel 7. Rekapitulasi Hasil Efektivitas Perangkat Pembelajaran

\begin{tabular}{lcc}
\hline \multicolumn{1}{c}{ Kriteria } & Uji Coba I & Uji Coba II \\
\hline Ketuntasan & X & $\sqrt{ }$ \\
Klasikal & $\sqrt{ }$ & $\sqrt{ }$ \\
\hline Aktivitas siswa & $\sqrt{ }$ \\
\hline Respon Siswa & Belum Efektif & Efektif \\
\hline Kefektifan &
\end{tabular}

\section{Peningkatan Kemampuan Komunikasi Matematis}

Data yang diperoleh dari hasil postes kemampuan komunikasi matematis siswa uji coba I dan uji coba II dianalisis untuk mengetahui peningkatan kemampuan komunikasi matematis siswa dengan membandingkan rata-rata skor siswa yang diperoleh dari hasil postes uji coba I dan uji coba II ditunjukkan pada Tabel 8.

Berdasarkan tabel di atas, diketahui bahwa rataan skor siswa uji coba I adalah sebesar 79,89 dan uji coba 2 yaitu $88,65 \%$.
Hal ini sesuai dengan analisis data peningkatan kemampuan komunikasi matematis siswa pada BAB III, yaitu peningkatan kemampuan komunikasi matematis dilihat dari rata-rata hasil postes uji coba I dan II, dengan demikian diketahui bahwa terjadi peningkatan nilai rata-rata kemampuan komunikasi matematis siswa sebesar 8,76.

Tabel 8. Rata-Rata Skor Post Test Komunikasi Matematis

\begin{tabular}{lcc}
\hline Keterangan & $\begin{array}{c}\text { Postest } \\
\text { Komunikasi } \\
\text { Matematis Uji } \\
\text { Coba I }\end{array}$ & $\begin{array}{c}\text { Postest } \\
\text { Komunikasi } \\
\text { Matematis Uji } \\
\text { Coba II }\end{array}$ \\
\hline $\begin{array}{l}\text { Nilai } \\
\text { Tertinggi }\end{array}$ & 95,8 & 95,8 \\
\hline $\begin{array}{l}\text { Nilai } \\
\text { Terendah }\end{array}$ & 62,75 & 70,83 \\
\hline Rata-rata & $\mathbf{7 9 , 8 9}$ & $\mathbf{8 8 , 6 5}$ \\
\hline
\end{tabular}

Peningkatan self-Efficacy siswa Uji Coba I dan Uji Coba II

Data yang diperoleh dari hasil angket self-efficacy siswa pada uji coba I dan uji coba II dianalisis untuk mengetahui peningkatan self-efficacy siswa. Peningkatannya dilihat dari membandingkan rata-rata skor angket self-efficacy siswa pada uji coba I dan uji coba I dapat dilihat pada Tabel 9 berikut.

Tabel 9. Hasil Rata-Rata Skor Angket Self-Efficacy

\begin{tabular}{lccc}
\hline Indikator & $\begin{array}{c}\text { Rata- } \\
\text { rata } \\
\text { Ujicoba } \\
\text { I }\end{array}$ & $\begin{array}{c}\text { Rata- } \\
\text { rata } \\
\text { Ujicoba } \\
\text { II }\end{array}$ & Peningkatan \\
\hline $\begin{array}{l}\text { Pengalaman } \\
\text { akan kesuksesan }\end{array}$ & 3,10 & 3,19 & 0,09 \\
\hline $\begin{array}{l}\text { Pengalaman } \\
\text { individu lain }\end{array}$ & 3,22 & 3,34 & 0,12 \\
\hline $\begin{array}{l}\text { Pendekatan } \\
\text { sosial }\end{array}$ & 3,09 & 3,18 & 0,09 \\
\hline $\begin{array}{l}\text { Kedaan fisologis } \\
\text { dan emosional }\end{array}$ & 3,25 & 3,30 & 0,05 \\
\hline
\end{tabular}

Analisis Proses Jawaban Siswa pada Tes Kemampuan Komunikasi Matematis

Proses jawaban siswa untuk kemampuan komunikasi matematis pada uji coba I dan uji coba II selengkapnya dapat dilihat pada Tabel 10 .

Berdasarkan Tabel 10 di atas, diketahui bahwa kebanyakan siswa memperoleh kategori baik dan cukup untuk masing-masing aspek kemampuan komunikasi matematis, hanya beberapa siswa yang memperoleh nilai proses jawaban yang kurang baik. Dari deskripsi proses jawaban kemampuan komunikasi matematis siswa pada uji coba I dan uji coba II, dapat disimpulkan bahwa proses jawaban siswa pada uji coba II lebih baik dibandingkan dengan proses jawaban siswa pada uji coba I. 


\begin{tabular}{|c|c|c|c|}
\hline \multirow{2}{*}{$\begin{array}{c}\text { Indikator } \\
\text { Kemampuan } \\
\text { Komunikasi } \\
\text { Matematis }\end{array}$} & \multicolumn{2}{|c|}{ Jumlah Siswa } & \multirow[b]{2}{*}{$\begin{array}{l}\text { Kategori } \\
\text { Penilaian }\end{array}$} \\
\hline & $\begin{array}{c}\text { Uji } \\
\text { Coba } \\
1 \\
\end{array}$ & $\begin{array}{c}\text { Uji } \\
\text { Coba } \\
2 \\
\end{array}$ & \\
\hline \multirow{3}{*}{$\begin{array}{l}\text { Menyatakan suatu } \\
\text { situasi, gambar, } \\
\text { diagram atau situasi } \\
\text { dunia nyata ke dalam } \\
\text { bahasa matematik, } \\
\text { simbol, idea, dan } \\
\text { model matematika }\end{array}$} & 26 & 30 & Baik \\
\hline & 8 & 10 & Cukup \\
\hline & 6 & 0 & $\begin{array}{c}\text { Kurang } \\
\text { Baik }\end{array}$ \\
\hline \multirow{3}{*}{$\begin{array}{l}\text { Menginterprestasikan } \\
\text { dan mengevaluasi } \\
\text { gagasan-gagasan } \\
\text { matematika baik secara } \\
\text { lisan maupun tertulis }\end{array}$} & 23 & 28 & Baik \\
\hline & 10 & 8 & Cukup \\
\hline & 7 & 4 & $\begin{array}{c}\text { Kurang } \\
\text { Baik }\end{array}$ \\
\hline \multirow{3}{*}{$\begin{array}{l}\text { Menyatakan suatu } \\
\text { argumen dalam } \\
\text { bahasanya sendiri. }\end{array}$} & 20 & 24 & Baik \\
\hline & 12 & 10 & Cukup \\
\hline & 8 & 6 & $\begin{array}{c}\text { Kurang } \\
\text { Baik }\end{array}$ \\
\hline \multirow{3}{*}{$\begin{array}{l}\text { Menyatakan suatu } \\
\text { situasi, gambar, } \\
\text { diagram atau situasi } \\
\text { dunia nyata ke dalam } \\
\text { bahasa matematik, } \\
\text { simbol, idea, dan } \\
\text { model matematika }\end{array}$} & 14 & 17 & Baik \\
\hline & 18 & 20 & Cukup \\
\hline & 8 & 3 & $\begin{array}{c}\text { Kurang } \\
\text { Baik }\end{array}$ \\
\hline \multirow{3}{*}{$\begin{array}{l}\text { Menginterprestasikan } \\
\text { dan mengevaluasi } \\
\text { gagasan-gagasan } \\
\text { matematika baik secara } \\
\text { lisan maupun tertulis }\end{array}$} & 15 & 18 & Baik \\
\hline & 20 & 21 & Cukup \\
\hline & 5 & 1 & $\begin{array}{c}\text { Kurang } \\
\text { Baik }\end{array}$ \\
\hline
\end{tabular}

\section{PEMBAHASAN HASIL PENELITIAN}

\section{Pengembangan Perangkat Pembelajaran Berbasis} Masalah yang Valid, Praktis, dan Efektif

Perangkat pembelajaran yang dikembangkan dalam penelitian ini adalah perangkat pembelajaran berorientasi pembelajaran berbasis masalah. Secara umum tujuan penelitian ini adalah menghasilkan suatu produk berupa perangkat pembelajaran yang dapat meningkatkan kemampuan komunikasi matematis siswa SMP. Eggen dan Kauchak (2012:307) menyatakan "pembelajaran berbasis masalah adalah seperangkat model mengajar yang menggunakan masalah sebagai fokus untuk mengembangkan keterampilan pemecahan masalah".

Pengembangan perangkat pembelajaran berbasis model pembelajaran berbasis masalah dalam penelitian ini dilakukan sesuai dengan prosedur model pengembangan Dick and Carey. Model pengembangan Dick and Carey terdiri dari sepuluh tahap yang saling berkaitan dan selalu dihubungkan dengan revisi, serta terdapat dua tahap evaluasi untuk mengasilkan suatu produk yang baik (Dick and Carey, 2005:2). Akker (1999) yang intinya dalam penelitian pengembangan model pembelajaran perlu kriteria kualitas yaitu kevalidan (validity), kepraktisan (practically), dan keefektifan (effectiveness)

Sebelum dilakukan uji coba terhadap perangkat pembelajaran yang dikembangkan maka terlebih dahulu perangkat yang dikembangkan di validasi oleh para ahli dan praktisi (validator). Setelah perangkat pembelajaran yang dikembangkan dinyatakan valid, kemudian dilakukan uji coba terhadap perangkat pembelajaran yang dikembangkan untuk melihat kepraktisan dan keefektifan perangkat pembelajaran tersebut.

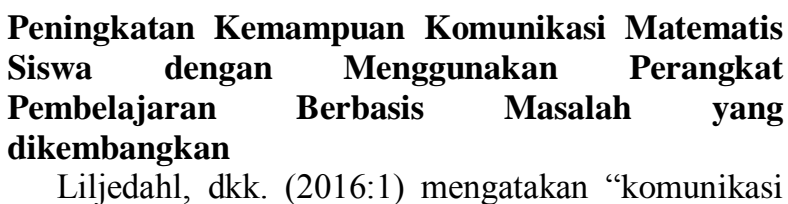
matematis telah lama dipandang sebagai aspek penting matematika, pengajaran matematika, dan pembelajaran matematika".

Karlimah (2010:4) menyatakan bahwa Menuliskan hasil penyelesaian masalah matematika, mendorong siswa untuk merefleksikan pekerjaan mereka dan mengklarifikasi ide-ide untuk mereka. Ketika siswa dilibatkan secara komunikatif dalam mengerjakan masalah matematis, berarti mereka diminta untuk memikirkan ide ide mereka, atau berbicara dan mendengarkan siswa lain, dalam berbagi ide, strategi dan solusi. Oleh karena itu keterampilan komunikasi matematis perlu pula dimiliki oleh siswa.

Dengan menggunakan perangkat pembelajaran yang dikembangkan, siswa terlebih dahulu diberikan suatu permasalahan dan menganalisis untuk menemukan suatu pengetahuan dengan bimbingan guru sesuai dengan prosedur pembelajaran model pembelajaran berbasis masalah sehingga dapat meningkatkan kemampuan komunikasi matematis siswa.

Oleh karena itu, dalam penelitian ini dapat disimpulkan bahwa perangkat pembelajaran berbasis masalah yang dikembangkan dapat meningkatkan kemampuan komunikasi matematis siswa. Ini terlihat dari rata-rata hasil post-test kemampuan komunikasi matematis siswa dari uji coba I dan uji coba II

Peningkatan Sef-Efficacy Siswa Menggunakan Perangkat Pembelajaran Berbasis Masalah yang Dikembangkan

Penelitian pengembangan perangkat pembelajaran untuk meningkatkan kemampuan pemecahan masalah matematis dan Sef-Efficacy oleh Simanungkalit, R (2016) dalam penelitiannya pada siswa SMP, menyimpulkan bahwa kualitas perangkat pembelajaran yang dikembangkan dengan model pembelajaran berdasarkan masalah meningkatkan Self-Eficacy setelah siswa menggunakan perangkat pembelajaran yang sudah dikembangkan

Berdasarkan hasil analisis data angket sikap sefefficacy siswa pada uji ciba 1 dan uji coba 2 menunjukkan bahwa sef-efficacy siswa meningkat (lebih baik). Peningkatan sef-efficacy ini dilihat dari rata-rata hasil angket sef-efficacy yang diisi siswa. 


\section{KESIMPULAN DAN SARAN \\ Kesimpulan}

1. Perangkat pembelajaran berbasis masalah yang dikembangkan telah memenuhi kriteria valid, yaitu berdasarkan penilaian validator dan ujicoba instrumen penelitian.

2. Perangkat pembelajaran berbasis masalah yang dikembangkan telah memenuhi kriteria praktis ditinjau dari penilaian ahli/praktisi menyatakan bahwa perangkat pembelajaran berbasis masalah yang dikembangkan dapat digunakan dengan sedikit revisi dan keterlaksanaan perangkat pembelajaran pada uji coba II mencapai $84 \%$ dengan kategori baik.

3. Perangkat pembelajaran berbasis masalah yang dikembangkan telah memenuhi kriteria efektif. Kriteria efektif ditinjau dari: (1) ketuntasan belajar siswa secara klasikal telah tercapai $92,5 \%$ pada uji coba II; (2) aktivitas siswa selama kegiatan belajar memenuhi kriteria toleransi waktu ideal yang ditetapkan; dan (3) respon siswa positif terhadap komponen-komponen bahan ajar dan kegiatan pembelajaran yang dikembangkan.

4. Peningkatan kemampuan komunikasi matematis siswa menggunakan perangkat pembelajaran berbasis masalah (PBM) yang dikembangkan dan ditinjau dari hasi rata-rata pencapaian kemampuan komunikasi matematis siswa meningkat dari uji coba I ke uji coba II.

5. Peningkatan self-efficacy siswa menggunakan perangkat pembelajaran berbasis masalah yang dikembangkan dan ditinjau dari angket dan pernyataan positif serta pertanyaan negatif kepada siswa menunjukkan peningkatan dari uji coba I ke uji coba II.

6. Proses jawaban siswa pada uji coba II lebih baik dari proses jawaban siswa pada uji coba I.

\section{Saran}

Berdasarkan hasil penelitian dan kesimpulan di atas, maka dapat disarankan beberapa hal sebagai berikut:

1. Perangkat pembelajaran berbasis masalah yang dikembangkan telah memenuhi aspek kevalidan, kepraktisan dan keefektifan, maka disarankan kepada guru untuk dapat menggunakan perangkat pembelajaran ini guna menumbuhkembangkan kemampuan komunikasi matematis siswa khususnya siswa kelas VII SMP/MTs.

2. Bagi peneliti lain yang hendak melakukan penelitian untuk mengukur self efficacy siswa agar dapat mencari indikator self efficacy yang lain agar dapat memperkaya ilmu peneliti tentang self efficacy.

3. Perangkat pembelajaran berbasis masalah yang dikembangkan ini dapat dijadikan rujukan untuk membuat suatu komponen bahan ajar dengan materi lain guna menumbuhkembangkan kemampuan penalaran matematis baik di tingkat satuan pendidikan yang sama maupun berbeda.
4. Peneliti selanjutnya yang akan melaksanakan penelitian terkaid sebaiknya melakukan tahap evaluasi formatif yang ideal pada sebagaimana yang dilakukan Dick and Carey, yaitu dengan mengikut sertakan evaluasi satu-satu oleh ahli, evaluasi satu-satu oleh peserta didik, uji coba kelompok kecil, dan uji coba lapangan. Hal tersebut diharapkan dapat menghasilkan perangkat yang lebih baik.

\section{DAFTAR PUSTAKA}

Akker, J. V. D. 1999. Principles and Methods of Development Research. Dalam Plomp, T; Nieveen, N; Gustafson, K; Branch, R.M; dan Van Den Akker, J (eds). Design Approaches and Tools in Education and Training. London: Kluwer Academic Publisher.

Bandura, A. 1994. Self-Reactive Influences. California : Stanford University University 1997. Self-Efficacy. California:Stanford

Eggen, P. \& kauchak, D. 2012. Strategi dan Model Pembelajaran Mengajarkan Konten dan keterlapilan Berpikir. Jakarta: Indeks

Joyce, B. 2011. Student Achievement Through Staff Development (3rd ed.). Alexandria, VA: Association for Supervision and Curriculum Development

Habibah, E. 2012. Achievement Motivation and SelfEfficacy in Relation to Adjustment among University Student.Malaysia: Journal of Social Sciences 6 (3): 333-339, ISSN 1549-3652 Science Publications

Karlimah. 2010. Pengembangan Kemampuan Komunikasi dan Pemecahan Masalah Serta Disposisi Matematis Mahasiswa PGSD Melalui Pembelajaran Berbasis Masalah. Bandung: Pendidikan Guru Sekolah Dasar Fakultas Ilmu Pendidikan UPI

Lijedhal, P. dkk. 2016. Problem Solving in Mathematics Education: ICME-13 Tpoikal Survey. Germany: Springer Open.

Mehdinezhad, V. 2012. Teachers' Instructional Beliefs About Student-Centered Pedagogy. Iran: International Journal on New Trends in Education and Their Implications April, May, June 2011 Volume:2 Issue:2 Article:5 ISSN 1309-6249

NCTM, (2000). Principles and standards for school mathematics. Reston, VA : NCTM.

Oktaviarini, A. 2015. Penerapan Model Pembelajaran Berbasis Masalah Untuk Meningkatkan Kemampuan Komunikasi Matematis. Yogyakarta: Seminar Nasional Matematika dan Pendidikan Matematika UNY. ISBN. 978-602-73403-0-5

Shadiq, F. 2004. Pemecahan Masalah, Penalaran dan Komunikasi. Yogyakarta: Diklat Instruktur/Pengembang Matematika SMA Jenjang DasarSinaga, B. 2007. Pengembangan Model Pembelajaran Matematika Berdasarkan Masalah Berbasis Budaya Batak (PBM-B3). Disertasi tidak 
Vol. 14, No. 1, Juni 2021

diterbitkan. Surabaya: Program Pacasarjana Universitas Negeri Surabaya.

Simanungkalit, R. 2016. Pengembangan Perangkat Pembelajaran untuk Meningkatkan kemampuan Pemecahan Masalah Matematis Siswa SMP Negeri 12 Pematangsiantar. Surabaya: Journal of Mathematics Education, Science and Technology. Vol. 1, No 1, Juli 2016. Hal 39-56

Sinaga, B. 2007. Pengembangan Model Pembelajaran Matematika Berdasarkan Masalah Berbasis Budaya Batak (PBM-B3). Disertasi tidak diterbitkan . Surabaya: Program Pascasarjana Universitas Negeri Surabaya.

Soedjadi. 2000. Pembelajaran Matematika Realistik. Surabaya : PMRI Lokal LPMP

Trianto,(2009). Mendesaian Model Pembelajaran Inovatif-Progresif. Jakarta: Bumi Aksara.

Wiryanto. 2004. Pengantar Ilmu Komunikasi. Jakarta: Grasindo

Wulandari, T. 2013. Penerapan Pembelaran IPS Berbasis Masalah (Problem Based Learning) Untuk Meningkatkan Karakter Rasa Ingin Tahu (Curiousity) Siswa. Bandung: Universitas Pendidikan Indonesia 